International Journal of Agriculture, Environment and Bioresearch

Vol. 5, No. 01; 2020

ISSN: $2456-8643$

\title{
TRANSMISSION EFFICIENCY OF RICE YELLOW MOTTLE VIRUS THROUGH DEHYDRATED RICE (ORYZA SATIVA L.) STRAW AND ROOTS
}

\author{
Kaboré Emmanuel $^{1,2}$, Nitiema W. Léon ${ }^{1}$, Sérémé Drissa ${ }^{1}$, Kuiré P. P. Epiphane ${ }^{1}$, Traoré M. Djibril ${ }^{3}$, Sorho \\ Fatogoma $^{4}$ and Simporé Jacques ${ }^{2}$ \\ ${ }^{1}$ Institute of Environment and Agricultural Research (INERA), Laboratory of Plant Virology and Biotechnology, 01 \\ BP 476 Ouagadougou, Burkina Faso \\ ${ }^{2}$ Joseph Ki-Zerbo University, Laboratory of Molecular Biology and Genetics, 03 BP 7021 Ouagadougou 03, Burkina \\ Faso \\ ${ }^{3}$ Institute of Rural Economy (IER), CRRA Sikasso, BP 16 Sikasso, Mali \\ ${ }^{4}$ Félix Houphouët-Boigny University, Laboratory of Plant Physiology, 22 BP 582, Abidjan, Côte d Tvoire
}

https://doi.org/10.35410/IJAEB.2020.5470

\begin{abstract}
Rice yellow mottle virus (RYMV; genus Sobemovirus) is the most important rice virus and is widely distributed in Africa. Investigatingon transmission modes and their efficiency is urgently needed to understand the factors contributing to the epidemiology of this viral disease. We investigated RYMV transmission through dehydrated straw and roots, and assessed the viability of virions over time under sun and shade-dehydrated conditions. Transmission via soil contaminated with RYMV-infected rice straw and roots was also examined. Rice yellow mottle virus was detected in sun-dried straw and roots until 70 days post harvesting and that independently to RYMV isolate used. This result was confirmed by ELISA test. Elimination of RYMV in rice plant residues during drying seems to result mainly from heat inactivation. Rice seedlings grown in pots containing a mixture of autoclaved soil and sun-dried straw and root contaminated with RYMV become infected when $8 \mathrm{mg}$ of RYMV-infected straw per $\mathrm{kg}$ of autoclaved soil and $50 \mathrm{ml}$ of infected root sap per $100 \mathrm{~g}$ of sterile soil. Altogether, the results demonstrated that RYMV is transmitted via rice plant residues such as straw and root, in which the virus survives for several weeks.
\end{abstract}

Keywords: RYMV, rice, transmission, dehydrated straw, dehydrated root, soil

\section{INTRODUCTION}

Rice (Oryza sativa L.) is a major staple crop as well as a cash crop in sub-Saharan Africa. However, since the early 1990s, rice production is severely affected by rice yellow mottle, the most important viral disease of rice in Africa. The causal agent is Rice yellow mottle virus (RYMV) of the plant virus genus Sobemovirus (Suvi et al., 2018). RYMV is an emergent virus, indigenous to Africa. It was first isolated in Kenya in East Africa in 1966 (Bakker, 1974) and since then in almost all African countries where rice is grown, including Burkina Faso (Kouassi et al., 2005) but not outside this continent.

Symptoms induced by the virus are highly variable including leaf mottling and yellowing, stunting, reduced tillering, non-uniform flowering, and plant death. Disease severity depends on 
Vol. 5, No. 01; 2020

ISSN: $2456-8643$

the rice genotype, the virus strain, the age of a plant at infection, and the climatic factors (Sorho et al., 2019). Depending on the rice genotypes, infectious strain, stage of infection and environment, crop damage by RYMV can be devastating causing variable yield losses that may reach $100 \%$ (Kouassi et al.,2005; Bewket, 2018).

Rice yellow mottle virus has a narrow host range restricted to the two cultivated rice species Oryza sativa and $O$. glaberrima, the wild rice species $O$. longistaminata and $O$. barthii and a few related wild Poaceae species (Bakker 1974). The virus is transmitted by chrysomelid beetles (Bakker 1974), by mammals (Sarra and Peters 2003), and by contact during cultural practices (Traoré et al., 2006). No evidence of seed transmission has been found in cultivated and wild rice species (Bakker, 1974; Fauquet and Thouvenel, 1977; Konaté et al., 2001; Allarangaye et al., 2006).

Virus management is difficult and the most effective and sustainable approach to the prevention of virus disease is through the deployment of genetic resistance targeted against viruses directly or, in theory, against their vectors (Maule et al., 2007). Current control measures against RYMV are mainly directed to the use of sources of resistance which have been identified in a limited number of cultivars from the two cultivated rice species $O$. saliva and $O$. globerrima (Ndjiondjop et al., 1999; Ioannidou et al., 2000, Sérémé et al., 2016).

Unfortunately, natural occurrence and prevalence of resistance-breaking RYMV isolates have been reported in West Africa. The emerging of resistance-breaking isolates is a threat to the success of genetic control of rice yellow mottle disease. Since then, in addition to resistance deployment, RYMV control should also include other means such as phytosanitary measures in an integrated management strategy. In principle, epidemiological approaches are therefore able to guide decisions on which strategies, including phytosanitary measures, are the most promising ones for the control of plant viruses (Jones et al., 2010). So, Knowledge of transmission and virion resilience under various conditions is important to understand the epidemiology of viruses. RYMV has been found to be infectious in irrigated water, guttation fluid (Traoré et al., 2008) and is able to infect plants via soils (Uké et al., 2014). Involvement of mammals such as cows, donkeys and rats (Sarra and Peters, 2003) and men via cropping practices (Traoré et al., 2006) has been reported. Wind-mediated transmission of RYMV has also been reported (Sarra et al., 2004). Other several means of transmission and sources of infection are suspected.

The present study aimed to determine whether RYMV is transmitted via dehydrated straw and by roots, and to assess the viability of virions over time under sun and shade-dehydrated conditions. Implications of the findings in the epidemiology and the control of rice yellow mottle disease are discussed.

\section{MATERIALS AND METHODS}

\subsection{Plant material}

For all the experiments, the same variety of rice, BG90-2 (Oryza sativa L.) originating from Sri Lanka, was used for inoculation and RYMV infection. This variety is highly susceptible to Rice yellow mottle virus.

\subsection{Virus isolate and propagation}


Altogether, two (02) RYMV isolates (Table 1) originating from our virus collection, and collected from rice in Mali (Ma207) and Cote d'Ivoire (Ci115) were used in this study. These isolates are fully representative of the geographic and pathogenic distribution of RYMV in SubSaharan Africa. It includes one resistance-breaking isolate (Ma207) and a non-resistancebreaking one (Ci115) (Sérémé, 2010). Before used, each isolate was propagated and maintained in the highly susceptible rice cultivar BG90-2 to increase virus concentration. The results were confirmed using ELISA.

Table 1. Origin, serological and pathogenic properties of RYMV isolates used

\begin{tabular}{|llll|}
\hline Isolates & Origin & Strain & Pathogenic status* \\
\hline Ma207 & Mali & $\mathrm{S} 1$ & $\mathrm{RB}$ \\
Ci115 & Côte d'Ivoire & $\mathrm{S} 2$ & $\mathrm{nRB}$ \\
\hline Isolates capability & $(\mathrm{RB})$ or not $(\mathrm{nRB})$ to overcome the high resistance of rice cultivar gigante
\end{tabular}

\subsection{Serological assay}

Double antibody sandwich enzyme-linked immunosorbent assay (DAS-ELISA) was used to detect the presence of the virus in samples according to Clark and Adams (1977). A polyclonal antibody that reacts strongly and similarly with all the RYMV isolates of West and Central Africa was used as the coating antibody (N'Guessan et al., 2000). This antibody was coupled to alkaline phosphatase and served as conjugate. All buffer system and incubation times were as previously described by Konate et al. (1997). For the detection of RYMV in the samples, analyses were done directly on extracts obtained after grinding the leaves ( $1 \mathrm{~g}$ in $10 \mathrm{ml}$ of buffer) and centrifugation at $8,000 \times \mathrm{g}$ for $10 \mathrm{~min}$. The mean absorbance value $\left(\mathrm{A}_{405} \mathrm{~nm}\right)$ from healthy controls plus three times the standard deviation was taken as the negative-positive threshold.

\subsection{Inoculum preparation and inoculation}

RYMV infected leaves of the susceptible rice cv. BG90-2 were collected and homogenized in $0.01 \mathrm{M}$ phosphate buffer $\mathrm{pH} 7.0$ at the ratio of $1: 10(\mathrm{w} / \mathrm{v})$ in a mortar. Carborundum $(600 \mathrm{mesh})$ was added to the extract as abrasive. The extract was rubbed onto the leaves of 2 -week-old seedlings which were subsequently rinsed with distilled water to remove superfluous inoculum and kept in an insect free glasshouse $\left(23-35^{\circ} \mathrm{C}\right.$ temperature and $80-90 \%$ humidity).

\subsection{Transmission by infected rice straw and roots}

BG90-2 seedlings plants were transplanted into 5-liter pots containing autoclaved soil. Fifteen plants per pot were inoculated with each virus isolates as described previously. The uninoculated plants (healthy plants) of each treatment were maintained as control. All assays were performed in triplicate, with three replicates per experiment.

From three weeks post-inoculation (21 dpi), RYMV-infected plants (infection confirmed by ELISA) were pulled out every week including leaves, stems and roots. Pulling out plants were kept at $-30^{\circ} \mathrm{C}$, and used as a source of inoculum in the experiments. These materials were then 
Vol. 5, No. 01; 2020

ISSN: $2456-8643$

sun-dried at $19-40.9^{\circ} \mathrm{C}$ temperature or shade-dried under a tree with a temperature comprises between $14.5^{\circ} \mathrm{C}$ and $39.9^{\circ} \mathrm{C}$. The relative humidity was in the range of $20 \% \sim 92 \%$.

In a second experiment BG90-2, seedlings infected by RYMV isolates Ma207 and Ci115 were separately sun-dried on mound. Sampling in the case of heaped straw was carried out on a superficial layer and upper horizon $(15 \mathrm{~cm})$ of straw.

In a third experiment, plants infected with isolates Ma207 and Ci115 were sun-dried in situ and used to evaluate the virus survival in the roots.

\subsection{Detection and infectivity of RYMV in rice dried straw and roots}

Dried materials including both straw and roots were subsequently used to inoculate susceptible cv BG90-2 at 3-5 leaf stage and maintained in an insect-proof greenhouse at $23-35^{\circ} \mathrm{C}$ and relative humidity of $80-90 \%$. Twenty plants per isolate were used. The appearance of symptoms was monitored during $45 \mathrm{dpi}$ and leaf samples were collected for virus detection via ELISA and back inoculation tests. Four replicates were done on each treatment, and experiments were carried out twice.

\subsection{Transmission via soil mixed with RYMV-infected straw and roots}

To investigate if virus transmission occurred via soils contaminated with infected dried straw and roots, previously dried materials including both straw and roots were used for the experiments. The contaminated soil was obtained by mixing soil previously sterilized by autoclave and RYMV inoculum. Briefly, the inoculum was prepared by grinding $0.3 \mathrm{~g}, 3 \mathrm{~g}$, and $30 \mathrm{~g}$ of sundried straw for one week in 1 liter of water. Inoculum was mixed with autoclaved soil at 0.08 $\mathrm{mg}, 0.8 \mathrm{mg}$ and $8 \mathrm{mg}$ of virus $/ \mathrm{kg}$ and distribute in 51 pots. Fifteen (15) plants per pot were used in four replicates. BG90-2 seedlings with 14-day-old rice plants were then transplanted after soil contamination. Control plants were mock-inoculated as above but without virus inoculum. All plants were housed in an insect-proofed glasshouse under $23-35^{\circ} \mathrm{C}$ temperature and relative humidity of $80-90 \%$.

To test transmission via soil mixed with RYMV-infected root sap, dried roots were taken from RYMV-infected rice plants and ground in water at a $1 / 10(\mathrm{w} / \mathrm{v})$ ratio. One, 50, or $100 \mathrm{ml}$ of sap were added to $100 \mathrm{~g}$ of RYMV-free soil in each pot. Fifteen plants per pot were also used in four replicates.BG90-2 seedlings were transplanted in each pot. The appearance of RYMV symptoms was monitored and confirmed by ELISA test.

\section{RESULTS}

\subsection{Transmission of RYMV via infected rice straw}

RYMV infection via sun-dried straw and straw dried on mound did not occur beyond 63 days (Table 2). Development of symptoms was much slower when Ci115 isolate was used. These results were confirmed with the use of ELISA.

The two (02) RYMV isolates, Ma207 and Ci115, were still detectable in straw 63 and 70 days respectively after sun-dehydration. Isolate Ma207 was also detectable 91 days after straw dehydration in the sun with a higher absorbance $\left(\mathrm{A}_{405} \mathrm{~nm}=0.27\right)$ than Ci115 isolate $\left(\mathrm{A}_{405} \mathrm{~nm}=\right.$ 0.03) (data not shown). Also, isolate Ma207 persists longer under sun-dehydrated straw than Ci115 ones (Table 2). As soon as the straw is dehydrated under shade, both isolates Ma207 and 
Vol. 5, No. 01; 2020

ISSN: $2456-8643$

Ci115 were still detectable more than 91 days after dehydration. At the same time, the two isolates were detectable 63 days after sun-dehydration when the sampling was performed in the superficial layer and more than 91 days when the sampling is done in the upper horizon of the mound $(15 \mathrm{~cm})$.

Table 2. Inoculation of seedlings via RYMV-infected straw that was dried at variable conditions

\begin{tabular}{|c|c|c|c|c|c|}
\hline \multirow{3}{*}{ Dried conditions } & \multirow{3}{*}{$\begin{array}{c}\text { Interval } \\
\text { No of days }\end{array}$} & \multicolumn{4}{|c|}{ RYMV isolates detection } \\
\hline & & \multicolumn{2}{|c|}{ Ma207 } & \multicolumn{2}{|c|}{ Ci115 } \\
\hline & & Symptoms* & ELISA** & Symptoms* & ELISA** \\
\hline \multirow{3}{*}{ Sun-dried straw } & {$[1-35[$} & + & $15 / 15$ & + & $13 / 15$ \\
\hline & {$[42-70[$} & + & $9 / 15$ & + & $8 / 15$ \\
\hline & {$[77-105[$} & - & $0 / 15$ & - & $0 / 15$ \\
\hline \multirow{3}{*}{ Sun-dried straw in shade } & {$[1-35[$} & + & $14 / 15$ & + & $10 / 15$ \\
\hline & {$[42-70[$} & + & $10 / 15$ & + & $8 / 15$ \\
\hline & {$[77-105[$} & + & $6 / 15$ & + & $4 / 15$ \\
\hline \multirow{3}{*}{$\begin{array}{l}\text { Sun-dried straw on mound } \\
\text { (surface) }\end{array}$} & {$[1-35[$} & + & $13 / 15$ & + & $13 / 15$ \\
\hline & {$[42-70[$} & + & $11 / 15$ & + & $9 / 15$ \\
\hline & {$[77-105[$} & - & $0 / 15$ & - & $0 / 15$ \\
\hline \multirow{3}{*}{$\begin{array}{l}\text { Sun-dried straw on mounds } \\
(15 \mathrm{~cm} \mathrm{dept})\end{array}$} & {$[1-35[$} & + & $14 / 15$ & + & $11 / 15$ \\
\hline & {$[42-70[$} & + & $11 / 15$ & + & $7 / 15$ \\
\hline & {$[77-105[$} & + & $5 / 15$ & + & $4 / 15$ \\
\hline
\end{tabular}

*Symptomatology: $(+)=$ RYMV symptoms $;(-)=$ No symptoms

**Infected/inoculated numbers tested by ELISA

\subsection{Transmission of RYMV via dried roots}

In this test, symptom development was scored. As in the case of straw transmission test, symptoms appearance was more rapidly when Ma207 isolate was used for the inoculation (Table $3)$. Indeed, in all dehydration conditions, the number of infected plants was more important when Ma207 isolate is used than when another one (Ci115) is used as inoculum. 
Vol. 5, No. 01; 2020

ISSN: $2456-8643$

RYMV isolates Ma207 and Ci115 were detected 35 days post sun-dehydration and 70 and 77 days respectively when the dehydration is performed under shade. In contrast, they were detected more than 91 days when dehydrated is done by keeping the roots in situ in the pots (Table 3).

Table 3. Inoculation of seedlings via RYMV-infected roots that was dried at variable conditions

\begin{tabular}{|c|c|c|c|c|c|}
\hline \multirow{3}{*}{ Dried conditions } & \multirow{3}{*}{$\begin{array}{c}\text { Interval } \\
\text { No of } \\
\text { days }\end{array}$} & \multicolumn{4}{|c|}{ RYMV isolates detection } \\
\hline & & \multicolumn{2}{|c|}{ Ma207 } & \multicolumn{2}{|c|}{ Ci115 } \\
\hline & & Symptoms* & ELISA** & Symptoms* & ELISA** \\
\hline \multirow{3}{*}{ Sun-dried roots } & {$[1-35[$} & + & $11 / 15$ & + & $9 / 15$ \\
\hline & {$[42-70[$} & - & $0 / 15$ & - & $0 / 15$ \\
\hline & {$[77-105[$} & - & $0 / 15$ & - & $0 / 15$ \\
\hline \multirow{3}{*}{$\begin{array}{l}\text { Sun-dried } \\
\text { shade }\end{array}$} & {$[1-35[$} & + & $10 / 15$ & + & $9 / 15$ \\
\hline & {$[42-70[$} & + & $10 / 15$ & + & $9 / 15$ \\
\hline & {$[77-105[$} & - & $0 / 15$ & - & $0 / 15$ \\
\hline \multirow{3}{*}{ In situ sun-dried roots } & {$[1-35[$} & + & $11 / 15$ & + & $11 / 15$ \\
\hline & {$[42-70[$} & + & $10 / 15$ & + & $9 / 15$ \\
\hline & {$[77-105[$} & + & $9 / 15$ & + & $7 / 15$ \\
\hline
\end{tabular}

*Symptomatology: $(+)=$ RYMV symptoms $;(-)=$ No symptoms

**Infected/inoculated numbers tested by ELISA

\subsection{Transmission via soil mixed with RYMV-infected straw and roots}

To investigate the possible transmission of RYMV through sterile soil mixed with RYMVinfected straw and roots, inoculum was prepared using infected dried straw and roots. Then, inoculum was used to infect the susceptible rice cultivar BG90-2. Symptom development was scored. Both the isolates were able to induce infection in BG90-2 plants with different efficiency depending on inoculum concentration used to mix with autoclaved soil (Table 4). 
International Journal of Agriculture, Environment and Bioresearch

Vol. 5, No. 01; 2020

ISSN: $2456-8643$

Table 4. Results of transmission via soil mixed with RYMV-infected straw and roots

\begin{tabular}{|c|c|c|c|c|c|}
\hline \multirow{3}{*}{$\begin{array}{c}\text { Dried conditions } \\
\text { (for one week) }\end{array}$} & \multirow{3}{*}{$\begin{array}{c}\text { Volume/quantity } \\
\text { of sap mixed }\end{array}$} & \multicolumn{4}{|c|}{ RYMV isolates detection } \\
\hline & & \multicolumn{2}{|c|}{ Ma207 } & \multicolumn{2}{|c|}{ Ci115 } \\
\hline & & Symptoms* & ELISA** & Symptoms* & ELISA** \\
\hline \multirow{3}{*}{$\begin{array}{l}\text { RYMV-infected } \\
\text { sun-dried straw } \\
\text { (mg/kg soil) }\end{array}$} & 0.08 & - & $0 / 15$ & - & $0 / 15$ \\
\hline & 0.8 & - & $0 / 15$ & - & $0 / 15$ \\
\hline & 8 & + & $11 / 15$ & + & $9 / 15$ \\
\hline \multirow{3}{*}{$\begin{array}{l}\text { RYMV-infected } \\
\text { sun-dried roots } \\
(\mathrm{ml} / 100 \mathrm{~g} \text { soil })\end{array}$} & 1 & - & $0 / 15$ & - & $0 / 15$ \\
\hline & 50 & + & $7 / 15$ & - & $5 / 15$ \\
\hline & 100 & + & $0 / 15$ & + & $0 / 15$ \\
\hline
\end{tabular}

*Symptomatology: $(+)=$ RYMV symptoms $;(-)=$ No symptoms

**Infected/inoculated numbers tested by ELISA

\section{DISCUSSION}

Plant virus epidemiology provides powerful tools to investigate key factors that contribute to virus epidemics in crops. When successful, epidemiological approaches help to guide decisions regarding plant protection strategies. Recent studies have unravelled several previously undescribed and unsuspected biotic and abiotic means of RYMV transmission (Traoré et al., 2009). These studies highlight the pivotal role played by man in the development and control of RYMV epidemics through different cropping practices. So, determination of different modes of transmission is very important for the development of strategies for RYMV protection.

Under natural conditions the transmission of RYMV takes place through guttation fluid, water, contaminated and also through contact between healthy and diseased plants during cultivation (Sarra et al., 2004). Such transmissions of RYMV were also reported by Traoré et Traoré (2008) and Uké et al., (2014). In West Africa, rice straw is left in the rice field or used in a variety of ways after harvest. It is obvious that infected roots and straw would provide a good source of inoculum to the crops. By the end of the crop season farmers leave residues as such, which gradually get mixed with the soil.

It is also possible that a small percentage of plants may be infected through straw residues of diseased plants and these provide inoculum for further spread of the disease.

Interestingly, our result reveals that sun-dried straw remains infectious just for nine weeks suggesting that the risk of infection through straw from RYMV-infected seedlings, may be reduced by drying the paddy fields or using longer furrow periods. In this condition, rotation with upland crops could be efficient to control RYMV. 
Vol. 5, No. 01;2020

ISSN: $2456-8643$

In our straw transmission, RYMV was detected in straw 91 days post dehydration. This result indicates that rice residues as straw can harbour the virus many times after harvesting. Similar results were obtained by many authors (Sarra, 2005; Bakker, 1974). These authors showed that RYMV could remain infectious in rice residues six months to at least one-year post-harvesting in dehydrated rice leaves on calcium chloride and maintained at $4^{\circ} \mathrm{C}$.

Our result also highlighted a rapid loss of RYMV infectivity when straw is sun-dehydrated rather than sun-dehydration under shade. This loss of infectivity could be due to the inactivation of the virus under the combined action of temperature and solar rays. A similar result in loss of infectivity was reported during maturation and dehydration of rice seeds (Konaté et al., 2001) and Poaceae (Allarangaye, 2003). These authors explained these results by the inactivation of the virus during the process of maturation and seed dehydration. The incubation time of crude extract of RYMV inoculated into a susceptible rice cultivar is 5-8 days (Bakker, 1970; Ndjiondjop et al., 2001). However following transmission by an insect, incubation times longer than 20 days (Bakker, 1970) or 21 days (Abo et al., 2000), due to the small number of virus particles causing disease (Hull, 2002), have been reported. In our experiments, symptoms were observed in susceptible rice seedlings BG90-2 only 21 days after inoculation of infected and sundehydrated rice straw sap and 15 days when the straw is sun-dehydrated under shade. The lengthening of the incubation time of RYMV in dehydrated straw in direct contact with the sun's rays is therefore probably due to the small number of viral particles in this type of plant material. RYMV isolates Ma207 and Ci115 were detected for several weeks in rice straw and root dehydrated in the sun after the loss of their infectivity. These results indicate that the only detection of the virus in these plant material does not a priori have epidemiological importance. In the same straw dehydration condition, RYMV isolate Ci115 remained more long time infectious than isolate Ma207 while it is not the most virulent. This result indicates that there was not a relationship between virulence and infectivity persistence.

Isolates were not able to induce infection in BG90-2 plants transplanted in the soil mixed with $0.8 \mathrm{mg}$ of sun-dried straw RYMV-infected per $\mathrm{kg}$ of soil. In our experiment, rice straw was finely ground favouring the release of viral particles before being incorporated in the soil. That is contrary to what happens in field conditions where straw is not crushed. Therefore unlikely, crop residues are a source of RYMV inoculum in the field after four to five months of sun-drying in the case of a single annual crop and one to two months when the double culture is practiced. Our conclusion is contrary to that reported by Sarra (2005). The fact that the straw is dehydrated could explain why RYMV does not appear systematically in the same plot from one season to another. Since soil contaminated with infected straw or roots could cause RYMV infection, appropriate management of roots or straw residues that can cause soil and water contamination in affected fields will be important for RYMV control.

\section{CONCLUSION}

In agriculture and in nature, RYMV may be harboured in the dried straw and roots of infected plants, from which they may become a source of infection. Dried straw and roots may also act as vehicles in which RYMV is spread over distance by air currents. An understanding and knowledge of the infectivity and transmission of RYMV will be beneficial in the development of control strategies against this pathogen. 
Vol. 5, No. 01; 2020

ISSN: $2456-8643$

\section{ACKNOWLEDGMENTS}

This research was partially supported by the International Foundation for Science (IFS), Stockholm, Sweden, through a grant to Kuiré P. P. Epiphane.

\section{REFERENCE}

Abo M.E., Alegbejo M.D., Sy A.A., 2000. An overview of the mode of transmission, host plants and methods of detection of Rice yellow mottle virus. J. Sustain. Agric., 17:19-36.

Allarangaye M.D., 2003. Etude de la transmission du virus de la panachure jaune du riz par les semences de Poaceae. Mémoire de DEA, Université de Ouagadougou, BP 702 Ouagadougou, Burkina Faso, 41p.

Allarangaye M.D., raoré O., Traoré E.V.S., Millogo R.J., Konaté G., 2006. Evidence of nontransmission of Rice yellow mottle virus through seeds of wild host species. Journal of Plant Pathology, 88: 307-313.

Bakker W., 1970. Rice yellow mottle, a mechanically transmissible virus disease of rice in Kenya. Netherlands Journal of Plant Pathology, 76: 53-63.

Bakker W., 1974. Characterization and ecological aspect of rice yellow mottle virus in Kenya. PhD Thesis, Agriculture University Wageningen, The Netherlands, 152p.

Bewket G.B., 2018. Review on integrated pest management of important disease and insect pest of rice (Oryzae sativa L.). World Scientific News 100: 184-196.

Clark M.F., Adams A.N., 1977. Characteristics of the microplate method of enzyme-linked immunosorbent assay for the detection of plant viruses. Journal of General Virology 34:475-483.

Fauquet C.M., Thouvenel J.C., 1977. Isolation of the rice yellow mottle virus in Ivory Coast. Plant Disease Reporter, 61: 443-446.

Hull R., 2002. Seed transmission of Viruses: current perspectives. In: Matthew's Plant Virology, Academic Press, San Diego, USA, p 363-386.

Ioannidou D., Lett J.M., Pinel A., Assigbetse K., Brugidou C., Ghesquière A., Nicole M., Fargette D., 2000. Responses of Oryza sativa japonica subspecies to infection with Rice yellow mottle virus. Physiological and Molecular Plant Pathology, 57: 177-188.

Jones R.A.C., Salam M.U., Maling T.J., Diggle A.J., Thackray D.J., 2010. Principles of Predicting Plant Virus Disease Epidemics. Annu. Rev. Phytopathol. 48:179-203.

Konaté G., Sarra S., Traoré O., 2001. Rice yellow mottle virus is seed-borne but not seed transmitted. European Journal of Plant Pathology, 107: 361-364. 
Vol. 5, No. 01; 2020

ISSN: $2456-8643$

Konaté G., Traoré O., Coulibaly M.M., 1997. Characterization of rice yellow mottle virus isolates in soudano-sahelian areas. Archives of Virology, 142: 1117-1124.

Kouassi N.K., N'Guessan P., Albar L., Fauquet C.M., Brugidou C., 2005. Distribution and characterization of Rice yellow mottle virus: a threat to African farmers. Plant Disease, 89: 124133.

Maule A.J., Caranta C., Boulton M.I., 2007. Sources of natural resistance to plant viruses: status and prospects. Molecular Plant Pathology 8: 223-31.

N' Guessan P., Pinel A., Caruana M., Frutos R., Sy A.A., Ghesquière A., Fargette D., 2000. Evidence of the presence of two serotypes of rice yellow mottle virus in Côte d'Ivoire. European Journal of Plant Pathology, 106: 167-178.

Ndjiondjop M.N., Albar L., Fargette D., Fauquet C., Ghesquière A., 1999. The genetic basis of high resistance to rice yellow mottle virus (RYMV) in cultivars of two cultivated rice species. Plant Dis. 83:931-935.

Ndjiondjop M.N., Brugidou C., Zang S., Fargette D., Ghesquière A., Fauquet C., 2001. High resistance to Rice yellow mottle virus (RYMV) in two cultivated rice cultivars is correlated to the failure of the cell-to-cell movement. Physiological and Molecular Plant Pathology, 59: 309316.

Sarra S., 2005. Novel insights in the transmission of Rice yellow mottle virus in irrigated rice. Ph.D. Thesis, Wageningen University, Wageningen, The Netherlands, 112 p.

Sarra S., Oevering P., Guindo S., Peters D., 2004. Wind mediated spread of rice yellow mottle virus (RYMV) in irrigated rice crops. Plant Pathology, 53: 148-153.

Sarra S., Peters D., 2003. Rice yellow mottle virus is transmitted by cows, donkeys, and grass rats in irrigated rice crops. Plant Disease, 87: 804-808.

Sérémé D., 2010. La protéine suppresseur P1 des virus de la panachure jaune du riz et du chiendent (Imperata cylindrica): diversité, étude fonctionnelle et applications en biotechnologies. Thèse de Doctorat unique, Université de Ouagadougou, Burkina Faso, 220 p.

Sérémé D., Ouédraogo I., Néya B.J., Zida P.E., Yao N., Sié M., 2016. Screening improved rice varieties (Oryza spp) for their resistance/tolerance to Rice yellow mottle virus in West Africa. Int J Agric Innov Res. 5: 481-486.

Sorho F., Guinagui Ndoua B., Bolou Bi Bolou A., Koné N., Kouassi A., Koné B., Koné D., 2019. Response of 20 rice genotypes to the Rice yellow mottle virus (RYMV) under natural infection conditions in the M'bé Valley of Côte d'Ivoire. International Journal of Sciences, 8(12): $1-8$. 
Vol. 5, No. 01; 2020

ISSN: 2456-8643

Suvi W.T., Shimelis H., Laing M., 2018. Breeding rice for rice yellow mottle virus resistance in Sub-Saharan Africa: a review. Acta Agriculturae Scandinavica, section b - soil \& plant science, 69 (2): 181-188.

Traoré A.S., Traoré O., 2008. Abiotic transmission of Rice yellow mottle virus through soil and contact between plants. Pak. J. Biol. Sci. 11 (6): 900-904.

Traoré M.D., Traoré V.S.E., Galzi-Pinel A., Fargette D., Konaté G., 2008. Abiotic Transmission of Rice yellow mottle virus Through Soil and Contact Between Plants. Pakistan Journal of Biological Sciences 11 (6): 900-904.

Traoré O., Pinel A., Hébrard E., Gumedzoé M.Y.D., Fargette D., Traoré A.S., Konaté G., 2006. Occurrence of resistance-breaking isolates of Rice yellow mottle virus in the West and Central Africa. Plant Dis. 90: 259-263.

Traoré O., Pinel-Galzi A., Sorho F., Sarra S., Rakotomalala M., Sangu E., Kanyeka Z., Sérég Y., Konatéa G., Fargette D., 2009. A reassessment of the epidemiology of Rice yellow mottle virus following recent advances in field and molecular studies. Virus Research 141 (2): 258-267.

Traoré O., Traoré M.D., Fargette D., Konaté G., 2006. Rice seedbeds as a source of primary infection by Rice yellow mottle virus. European Journal of PlantPathology, 115: 181-186.

Uke A., Tibanyendela N., Ikeda R., Fujiie A.,Natsuaki K.T., 2014. Modes of transmission and stability of Rice yellow mottle virus. Journal of Plant Protection Research, 54, 363-366. 